ИЗВЕСТИЯ АКАДЕМИИ НАУК ЭСТОНСКОИ ССР. ТОМ 26 ХИМИЯ * ГЕОЛОГИЯ. 1977, № 4

Х. СТУМБУР

\title{
О ПУТЯХ ИСПОЛЬЗОВАНИЯ ГОРЮЧИХ СЛАНЦЕВ \\ В ЗАВИСИМОСТИ ОТ КАЧЕСТВА ИХ ОРГАНИЧЕСКОГО ВЕЩЕСТВА
}

Вопрос рассматривается на примере горючих сланцев нескольких сланцевых бассейнов и месторождений СССР и месторождения Грин Ривер (Колорадо, США). По этим месторождениям мы располагали достаточным количеством анализов для получения их достоверных средних значений (Геология месторождений угля и горючих сланцев СССР; Файнберг, 1975). Чтобы устранить влияние количественного содержа-

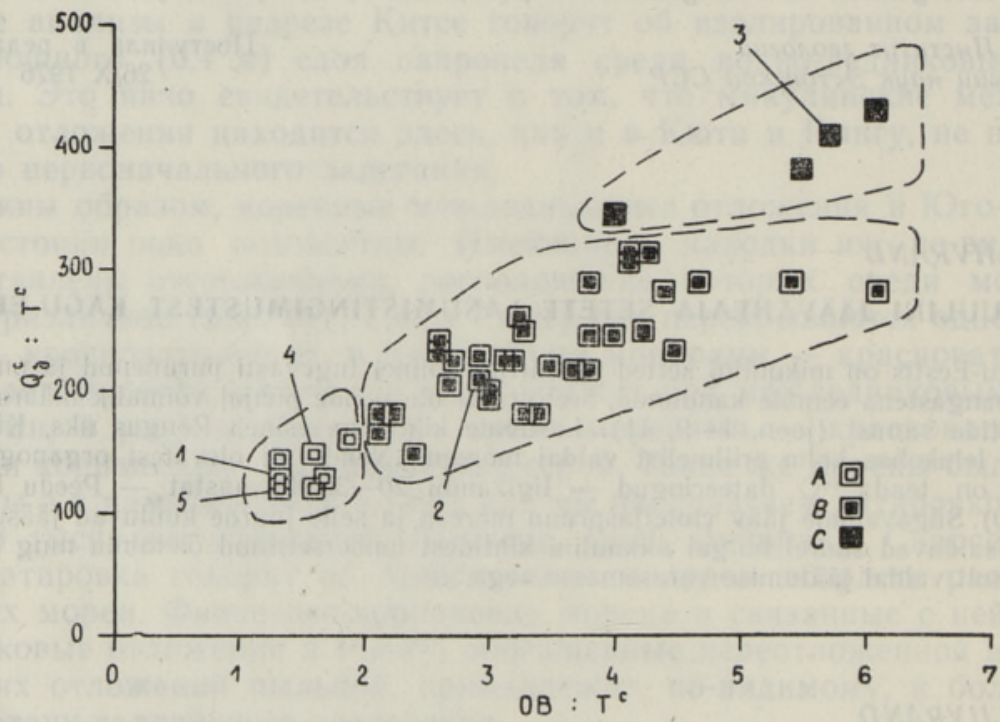

Рис, 1. Ког реляция между величинами отношений $\mathrm{OB}: T^{\mathrm{c}}$ и $Q_{\delta}^{\mathrm{c}}: T^{\mathrm{c}}$ для горючих сланцев групп $A, B$ и $C$. Месторождения: 1 - Эстонское, 2 - Кашпирское, 3 - Маардуское, 4 - Ленинградское, 5 горючие сланцы свиты Грин Ривер (Колорадо, США).

ния органического вещества (OB) на группирование горючих сланцев по качеству и свойствам ОВ, корреляция между такими его показателями, как теплота сгорания на сухую массу $Q_{\delta}^{\mathrm{c}}$, выход смолы по Фишеру $T^{\mathrm{c}}$, процентное содержание ОВ, содержание углерода и водорода в OB, рассмотрена нами не по абсолютным их значениям, а по вели- 


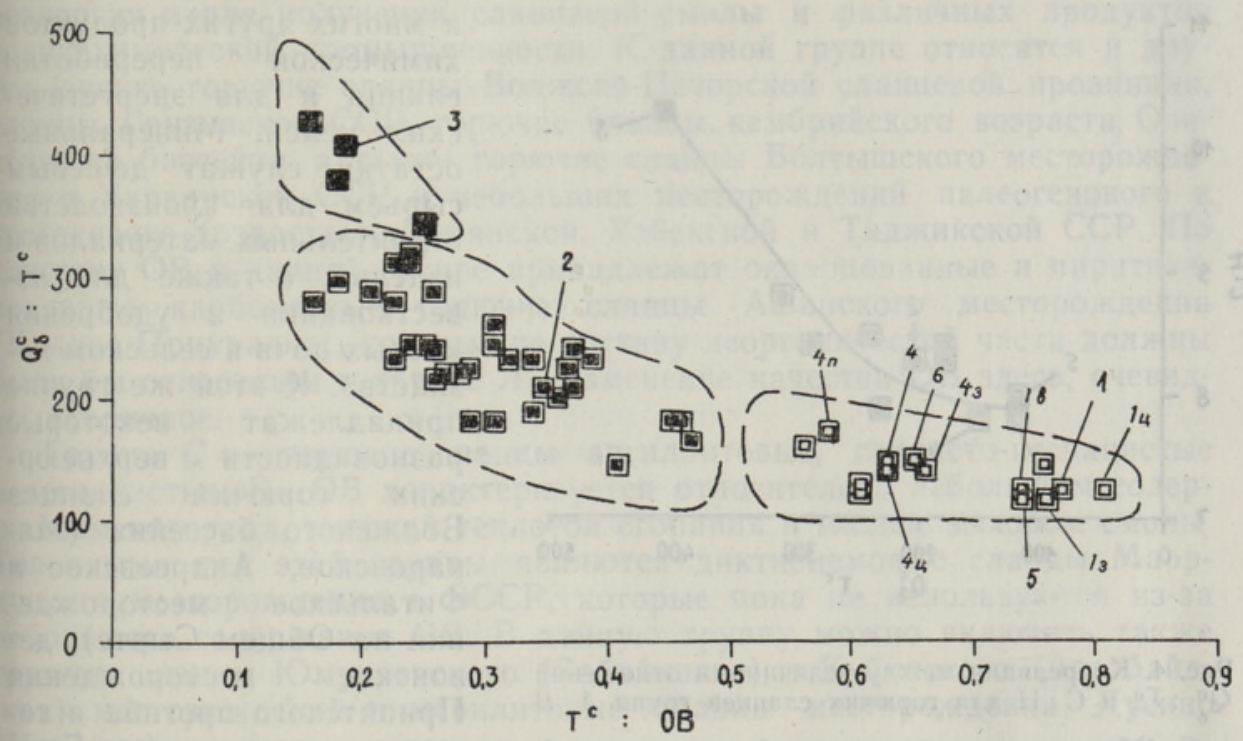

Рис. 2. Корреляция между величинами отношений $T^{\mathrm{c}}: \mathrm{OB}$ и $Q_{\diamond}^{\mathrm{c}}: T^{\mathrm{c}}$ для горючих сланцев групп $A, B$ и $C .1_{3}$ д, в - западный, центральный и восточный участки Эстонского месторождения; $4_{3}$, п, - западный, центральный и поисковый участки Ленинградского месторождения; 6 - Веймарнское месторождение. Остальные обозначения см. на рис. 1 .

чинам соотношений $\mathrm{H}: \mathrm{C}, \mathrm{C}: \mathrm{H}, Q_{\delta}^{\mathrm{c}}: T^{\mathrm{c}}, T^{\mathrm{c}}: \mathrm{OB}, \mathrm{OB}: T^{\mathrm{c}}$ (см. рис. $\left.1-4\right)$ ). Выяснилось, что горючие сланцы с одинаковым составом минеральной части вне зависимости от их возраста и генетического типа занимают на графиках корреляции одно определенное поле. Это указывает на различие качества и химического состава ОВ горючих сланцев каждого такого поля.

Горючие сланцы подразделены нами по качеству и свойствам ОВ в зависимости от вещественного состава неорганической части на три группы - $A, B$ и $C$, которым можно дать различную оценку по их промышленному значению и использованию.

Группа $A-$ горючие сланцы известковые, мергелистые и глинисто-мергелистые. Для их ОВ характерны высокое содержание водорода, высокая степень перехода в смолу и относительно низкая теплота сгорания. Типичными представителями данной группы являются кукерситы Прибалтийского бассейна, которые в настоящее время используются

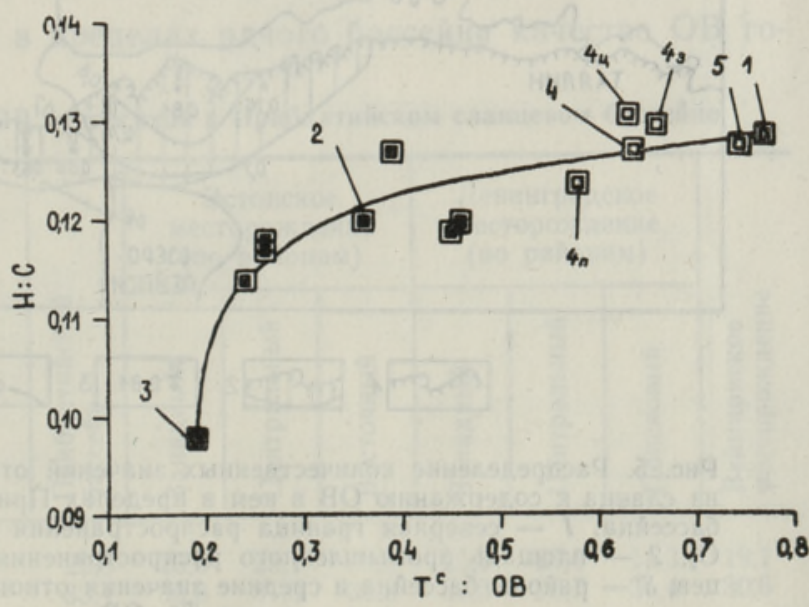

Рис. 3. Корреляция между величинами отношений $T^{\mathrm{c}}: \mathrm{OB}$ и $\mathrm{H}: \mathrm{C}$ для горючих сланцев групп $A, B$ и $C$. Обозначения месторождений см. на рис. 1 и 2. 


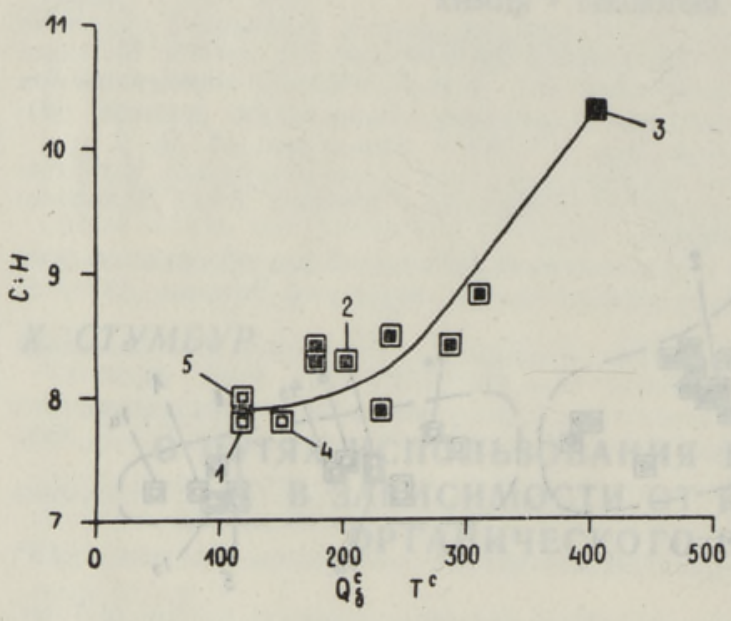

Рис. 4. Корреляция между величинами отношений $Q_{\delta}^{\mathrm{c}}: T^{\mathrm{c}}$ и С : Н для горючих сланцев групп $A, B$ и $C$. Обозначения месторождений см. на рис. 1.

для получения смолы, газа и многих других продуктов химической переработки сланца и для энергетиче. ских целей. Минеральные остатки служат дешевым сырьем для производства строительных материалов и изделий, а также для известкования и удобрения кислых почв в сельском хозяйстве. $\mathrm{K}$ этой же группе принадлежат некоторые разновидности верхнеюрских горючих сланцев Волжского бассейна (Maкаровское, Андреевское и Фитальское месторождения на Общем Сырте), девонские месторождения Припятского прогиб́а и горючие сланцы свиты Грин Ривер.

Группа $B$ - горючие сланцы глинистые, известково-глинистые, кремнистые, а также известковистые с кремнеземом, пиритом, магнетитом и кварцем. Их ОВ по сравнению с ОВ первой группы характеризуется меньшим содержанием водорода в отношении углерода, меньшим выходом смолы, несколько повышенной теплотой сгорания: Типичными для этой группы являются горючие сланцы Кашпирского месторождения, которые используются в настоящее время для производства элект.

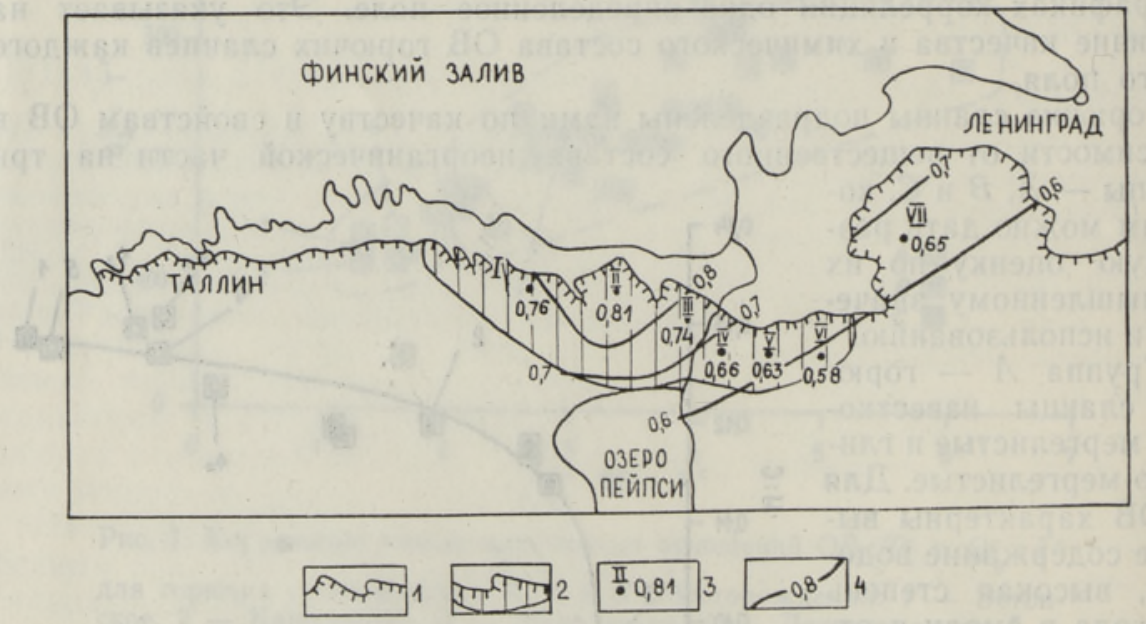

Рис. 5. Распределение количественных значений отношений выхода смолы из сланца к содержанию ОВ в нем в пределах Прибалтийского сланцевого бассейна: 1 - северная граница распространения кукрузеского горизонта $\mathrm{O}_{2}, 2$ - площадь промышленного распространения пласта горючих сланцев, 3 - районы бассейна и средние значения отношений $T^{\mathrm{c}}: \mathrm{OB}, 4-$ изолиний $T^{\mathrm{c}}: \mathrm{OB}$.

Участки Әстонского месторождения: I - западный, II - центральный, III - восточный. Участки Ленинградского месторождения: IV - западный, V - центральный, VI - поисковый. VII - Веймарнское месторождение. 
роэнергии и для получения сланцевой смолы и различных продуктов сланцехимической промышленности. К данной группе относятся и другие юрские горючие сланцы Волжско-Печорской сланцевой провинции, сланцы Грузинской ССР, горючие сланцы кембрийского возраста Оленёкского бассейна, а также горючие сланцы Болтышского месторождения в Украинской ССР и небольших месторождений палеогенового и неогенового возраста в Армянской, Узбекской и Таджикской ССР. По качеству ОВ к данной группе принадлежат окварцованные и пиритизированные карбонатные горючие сланцы Ашинского месторождения (Южное Приуралье), которые по составу неорганической части должны были бы относиться к группе $A$. Изменение качества ОВ здесь, очевидно, вторичное.

Группа $C$ - горючие сланцы аргиллитовые, глинисто-песчанистые и песчанистые. Их ОВ характеризуется относительно небольшим содержанием водорода, высокой теплотой сгорания и малым выходом смолы. Типичными для этой группы являются диктионемовые сланцы Маардуского месторождения в ЭССР, которые пока не используются из-за небольшого содержания ОВ. В данную группу можно включить также горючие сланцы Юмурченского (Забайкалье) и Кубинского (Азербайджан) месторождений и менилитовые сланцы месторождения Дусино (У

Из анализа рис. 1 и 2 вытекают следующие интересные факты. Чем больше в сланце ОВ, тем выше теплота сгорания ОВ и тем меньше выход из него смолы. Известковые и мергелистые горючие сланцы обладают большим выходом смолы из ОВ $(50-80 \%)$, а глинистые - малым $(10-50 \%)$. Теплота сгорания ОВ горючих сланцев повышается с увеличением в них содержания кварца. ОВ глинисто-кварцевых и песчанистых горючих сланцев (диктионемовых и менилитовых) перекрывает по этому показателю ОВ карбонатных горючих сланцев (кукерситов) более чем в четыре раза. Хорошая способность перехода ОВ в смолу связана с высоким содержанием в нем водорода (Файнберг, 1975). Почти идеально выраженная форма кривой на рис. 3 говорит о том, что едва ли можно найти еще такие горючие сланцы, у которых выход смолы из ОВ был бы больше, чем у кукерситов. Наоборот, повышение теплоты сгорания ОВ связано с увеличением в нем содержания углерода (рис. 4).

Следует отметить, что в пределах одного бассейна качество ОВ го-

\section{Характеристика качества ОВ кукерситов в Прибалтийском сланцевом бассейне}

\begin{tabular}{|c|c|c|c|c|c|c|c|c|}
\hline \multirow[b]{2}{*}{ Параметры } & \multirow[b]{2}{*}{ 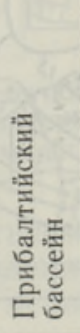 } & \multicolumn{3}{|c|}{$\begin{array}{c}\text { Эстонское } \\
\text { месторождение } \\
\text { (по районам) }\end{array}$} & \multicolumn{3}{|c|}{$\begin{array}{l}\text { Ленинградское } \\
\text { месторождение } \\
\text { (по районам) }\end{array}$} & \multirow[b]{2}{*}{ 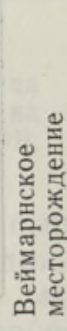 } \\
\hline & & लू & 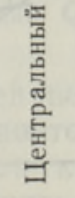 & 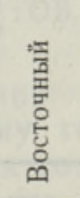 & 贸 & 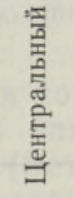 & 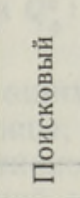 & \\
\hline $\begin{array}{l}\text { Выход смолы из сланца, } \% \\
\text { Содержание ОВ в сланце, \% }\end{array}$ & $\begin{array}{l}22,8 \\
33,4\end{array}$ & $\begin{array}{l}23,5 \\
30,8\end{array}$ & $\begin{array}{l}25,1 \\
31,0\end{array}$ & $\begin{array}{l}24,8 \\
33,8\end{array}$ & $\begin{array}{l}25,8 \\
39,3\end{array}$ & $\begin{array}{l}23,0 \\
36,7\end{array}$ & $\begin{array}{l}18,3 \\
31,4\end{array}$ & $\begin{array}{l}19,1 \\
30,6\end{array}$ \\
\hline $\begin{array}{l}\text { Теплота сгорания сланца, } \\
\text { ккал/ка } \\
\text { Содержание углерода в ОВ, \% } \\
\text { Содержание водорода в ОВ, \% }\end{array}$ & $\begin{array}{r}3096 \\
76,0 \\
9,8\end{array}$ & $\frac{2742}{-}$ & $\begin{array}{r}3117 \\
74,6 \\
9,6\end{array}$ & $\frac{3038}{-}$ & $\begin{array}{l}3575 \\
78,6 \\
10,2\end{array}$ & $\begin{array}{l}3188 \\
78,3 \\
10,3\end{array}$ & $\begin{array}{r}3057 \\
72,6 \\
9,0\end{array}$ & $\begin{array}{l}2957 \\
-\end{array}$ \\
\hline
\end{tabular}




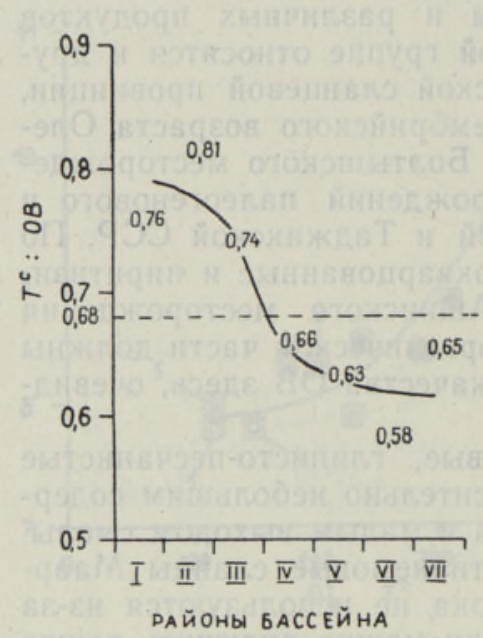

Рис. 6. Изменение величин отношения выхода смолы из сланца к содержанию ОВ в нем (названия районов бассейна см. на рис. 5). рючих сланцев может варьировать в больших пределах в зависимости от фациальных условий формирования сланцевой залежи (Бауков, Стумбур, 1975). Так, например, в западной части Прибалтийского бассейна (Эстонское месторождение) выход смолы из ОВ кукерсита колеблется от 71 до $81 \%$, а в восточной части (Ленинградское месторождение) - от 58 до $66 \%$. Изменение выхода смолы в разных частях бассейна имеет статистическое значение (таблица, рис. $2,5-8$ ). Более резко теплота сгорания и содержание углерода в ОВ горючих сланцев Прибалтийского бассейна изменяются в восточном и юго-восточном направлениях (рис. 9 и 3). Изменение калорийности ОВ кукерсита в бассейне имеет статистический характер (рис. 10). Качество ОВ кукерситов связано с количеством и составом минеральной части - глины, кварцевого материала, карбонатов, распределение которых хорошо согласуется с рельефом кристаллического фундамента.

Подобное наблюдается и в пределах Волжского сланцевого бассейна. Так, более высокой степенью выхода смолы из ОВ обладают мергелисто-глинистые горючие сланцы в юго-восточной части бассейна (Фитальское, Макаровское и Андреевское месторождения) и менее высокой - остальные месторождения этого бассейна, где карбонатность сланцев ниже.

Из сказанного следует, что при геолого-экономической оценке сланцевых месторождений наряду с другими их параметрами следует учитывать и качество и свойство ОВ горючих сланцев, так как от этого в определенной мере зависит выбор рационального направления исполь-
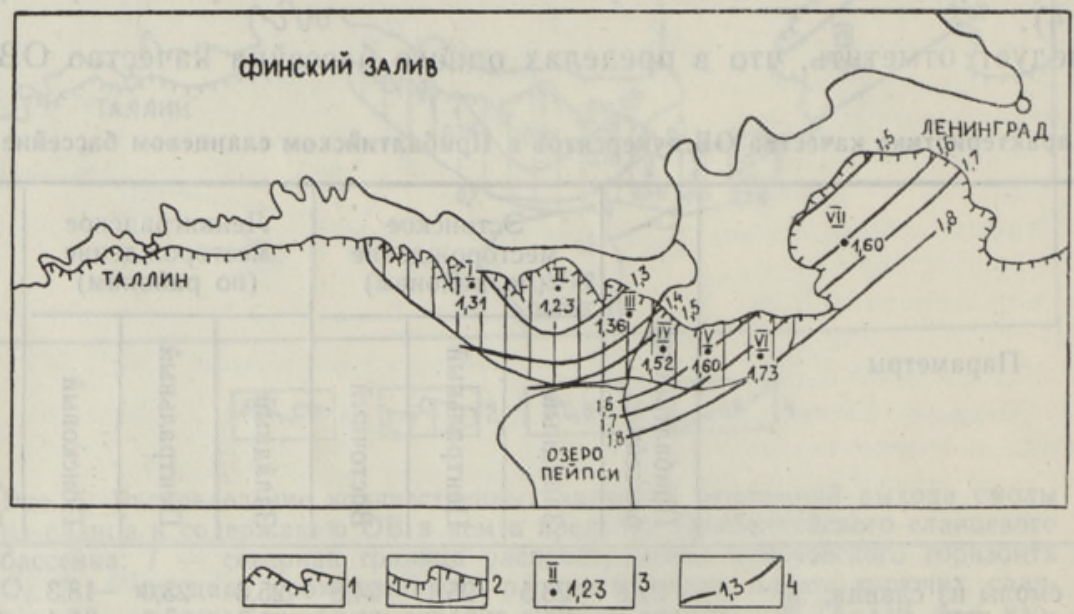

Рис. 7. Распределение величин отношения содержания ОВ в сланце к выходу смолы (названия районов см. на рис. 5): 1 и 2 см. на рис, $5,3-$ средние значения отношений ОВ: $T^{\mathrm{c}}, 4-$ изолинии ОВ : $T^{\mathrm{c}}$. 
зования последних в народном хозяйстве. Поясним это на примерах. Месторождения горючих сланцев, ОВ которых бедно по содержанию, но дает богатый выход смолы (сланцы Грин Ривер и др.), могут иметь промышленное значение. Далее. С уменьшением выхода смолы из ОВ пропорционально увеличивается теплота сгорания смолы: у сланцев группы $A$ она составляет приблизительно 6000 ккал/к2 (Эстонское месторождение), а в группе $B-10000$

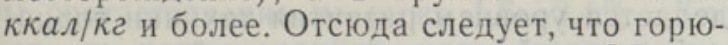
чие сланщы с малым содержанием ОВ, калорийность которых недостаточна для их прямого сжигания, можно использовать по энерготехнологической схеме с предварительным извлечением топливного масла. Низкокалорийная сланцевая смола с высо-

Рис. 8. Изменение величин отношения содержания ОВ в сланце к выходу смолы из сланца (названия районов см. на рис. 5).

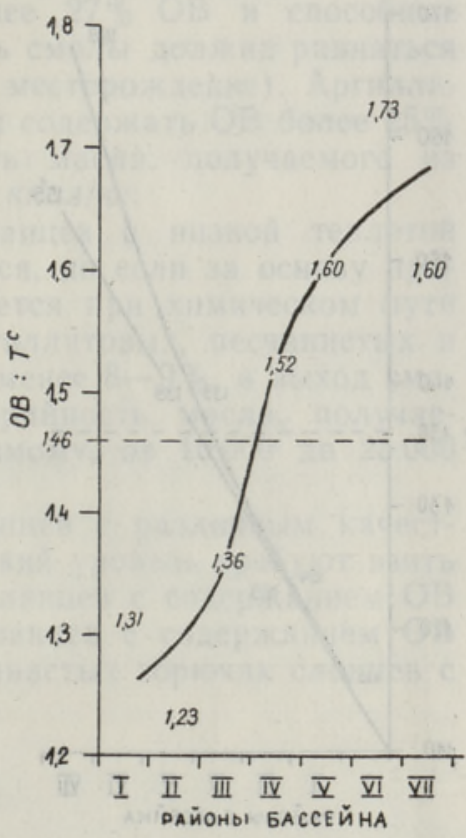

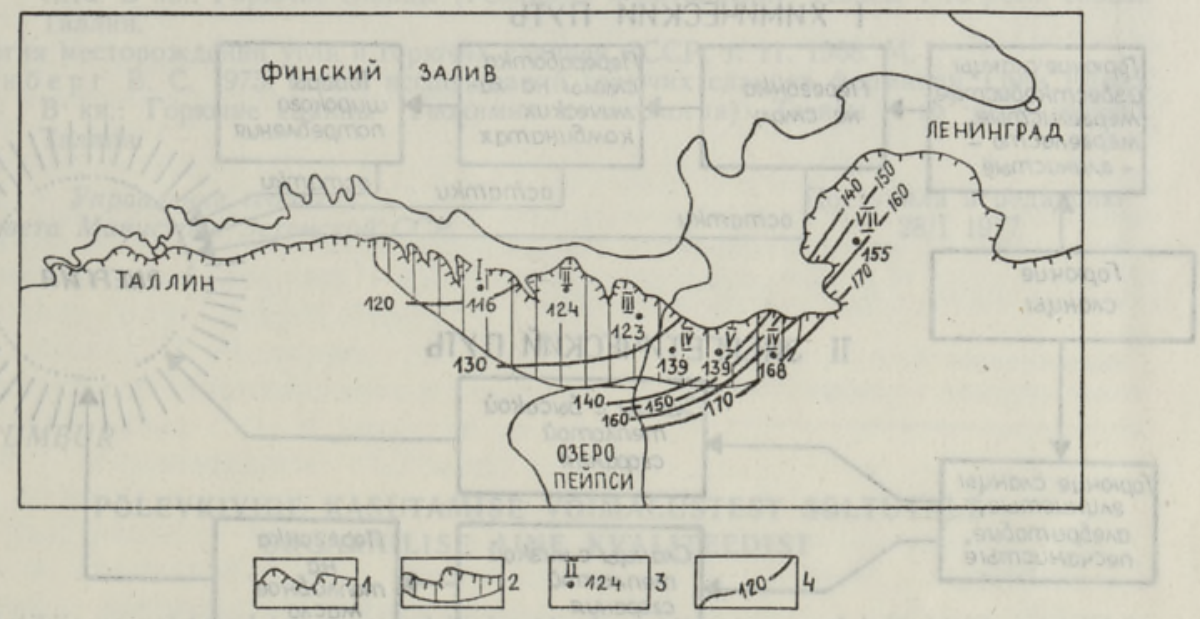

Рис. 9. Распределение величин отношения теплоты сгорания сухого сланца к содержанию ОВ в нем (названия районов см. на рис. 5): 1 и 2 см. на pис. $5,3-$ средние значения отношений $Q_{8}^{\mathrm{c}}: \mathrm{OB}, 4-$ изолинии $Q_{8}^{\mathrm{c}}: \mathrm{OB}$.

ким содержанием ароматических соединений является хорошим сырьем для химической промышленности, поэтому горючие сланцы, дающие такую смолу, невыгодно использовать как топливо (Эстонское месторождение). При этом следует учитывать, что месторождений карбонатных горючих сланцев в СССР значительно меньше, чем месторождений других групп.

Таким образом, по выходу смолы из ОВ и теплоте сгорания ОВ использование горючих сланцев рационально вести по двум основным направлениям: выработка электроэнергии при прямом сжигании сланца 


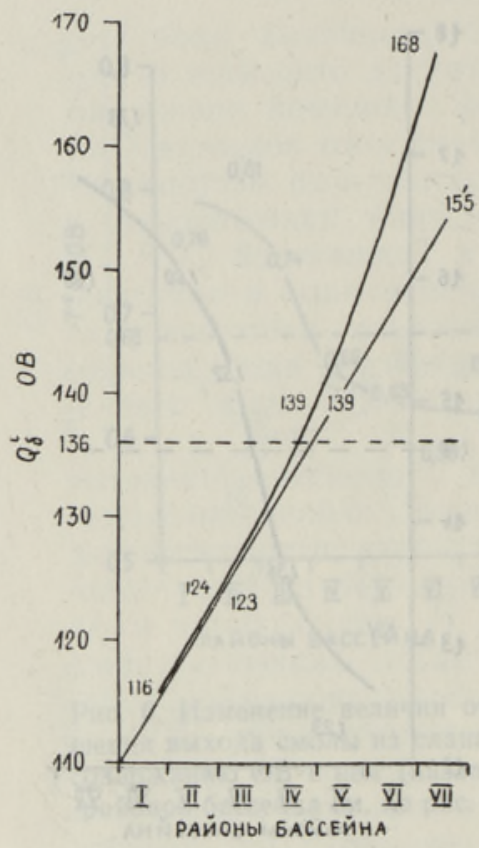

и по энерготехнологической схеме с получением различных химических продуктов и использованием остатков производства для выработки электроэнергии. По первому направлению использованию подлежат горючие сланцы групп $B$ и $C$, а по второму горючие сланцы группы $A$. Эти группы на рис. 2 разделяются линией ординаты, восстановленной из точки 0,4 .

Минимальное содержание ОВ для обоих путей использования горючих сланцев определяется уровнем развития техники горнодобывающей, сланцехимической и энергетической промышленности, а также ценами на конечные продукты переработки горючих сланцев.

За минимальное содержание ОВ горючих сланцев свиты Грин Ривер для

Рис. 10. Изменение величин отношений теплоты сгорания сухого сланца к содержанию ОВ в нем (названия районов см. на рис, 5).

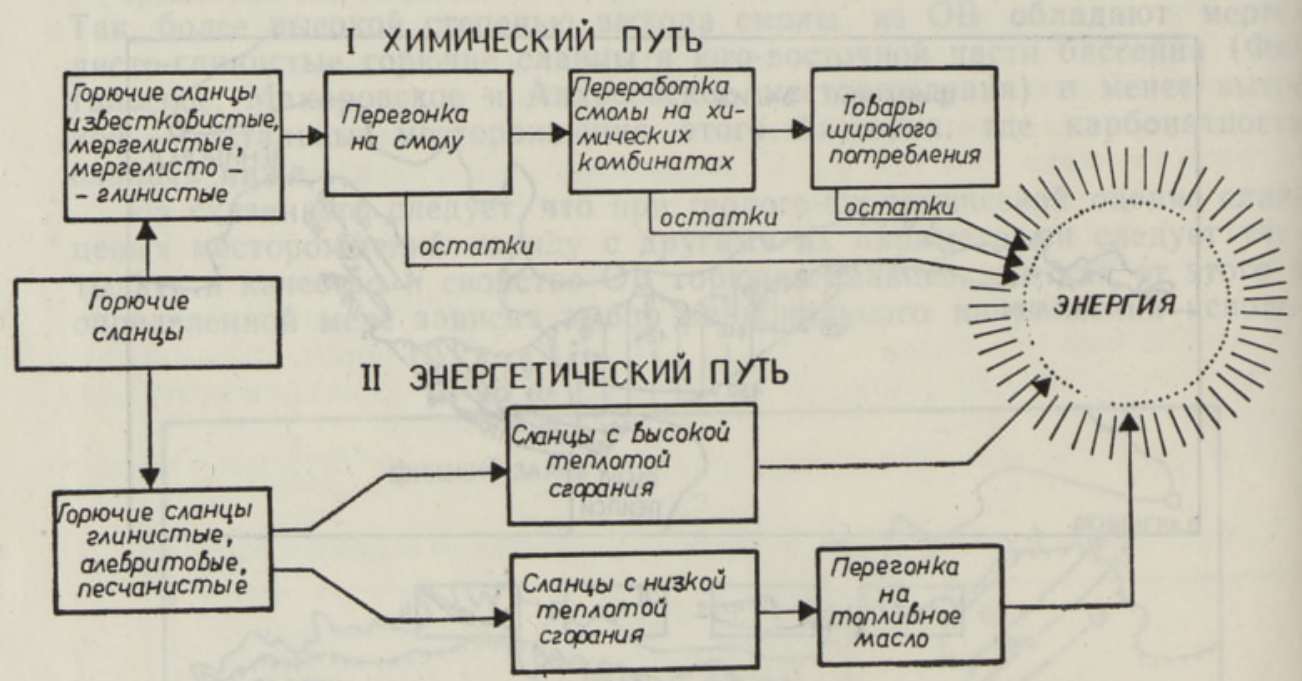

Рис. 11. Схема путей использования горючих сланцев в зависимости от качества их ОВ.

химического пути их использования берется $7 \%$, что дает теплоту сгорания сланца, равную всего 680 ккал/к2. Из одной тонны сланцев такого качества получается $56 \Omega$ смолы с высоким содержанием ароматических органических соединений. Теплота сгорания смолы такой группы горючих сланцев равняется 6000 ккал/ке. После выделения легких фракций получается топливное масло, теплота сгорания которого составляет около $9000 \kappa \kappa a \Omega / \kappa 2$, что вполне достаточно для получения тепловой энергии.

Пути использования горючих сланцев разных групп схематично показаны на рис. 11. Для прямого сжигания применяются сланцы с высо- 
кой теплотой сгорания, содержащие не менее $27 \%$ ОВ и способные давать выход смолы около 9\%. Калорийность смолы должна равняться приблизительно 10000 ккал/кг (Кашпирское месторождение). Аргиллитовые и песчанистые горючие сланцы должны содержать ОВ более $25 \%$ и давать выход смолы до $4 \%$. Калорийность масла, получаемого из

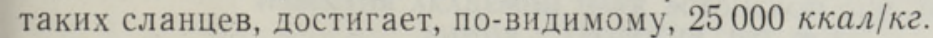

Возможности использования горючих сланцев с низкой теплотой сгорания в настоящее время только изучаются, но если за основу принять тот минимум энергии, который получается при химическом пути их использования, то содержание ОВ в аргиллитовых, песчанистых и глинистых горючих сланцах должно быть не менее 8-9\%, а выход смолы соответственно не ниже 1,6-3,4\%. Калорийность масла, получаемого из таких сланцев, колеблется, по-видимому, от 10000 до 25000

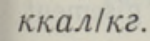

Разные пути использования горючих сланцев с различным качеством и свойством ОВ и современный технический уровень требуют взять на учет запасы всех карбонатных горючих сланцев с содержанием ОВ не менее $7 \%$, запасы глинистых горючих сланцев с содержанием ОВ не менее $9 \%$ и запасы аргиллитовых и песчанистых горючих сланцев с содержанием ОВ не менее $8 \%$.

\section{ЛИ ТЕРА Т У Р А}

Бауков С. С., Стумбур Х. А. 1975. Геологические условия образования кукерсита. В кн.: Горючие сланцы (Геохимия и литология). Тезисы 1-го респ. совещ. Таллин.

Геология месторождений угля и горючих сланцев СССР, т. 11. 1968. М.

$Ф$ ай н бе р г В. С. 1975. Итоги исследований горючих сланцев формации Грин Ривер. В кн.: Горючие сланцы (Геохимия и литология). Тезисы 1-го респ. совещ. Таллин.
Управление геологии
Совета Министров Эстонской ССР
Поступила в редакцию

\section{H. STUMBUR}

\section{PÓLEVKIVIDE KASUTAMISE VÓMALUSTEST SÓLTUVALT ORGAANILISE AINE KVALITEEDIST}

Artiklis on eristatud kolm gruppi kivimeid: $A$ - bituminoossed lubjakivid, merglid ja kukersiidid (tüüpleiukoht Balti bassein); $B$ - bituminoossed lubjakad savid ja savid (tüüpleiukoht Kašpir); $C$ - bituminoossed argilliidid ja liivakivid (tüüpleiukoht Maardu).

Orgaanilise aine omaduste järgi võib bituminoosseid kivimeid kasutada kas keemilise tooraine või soojusenergia saamiseks. Keemiliseks tooraineks sobib bituminoossetest lubjakividest, merglitest ja lubjakatest savidest saadud vesinikurikas õli, kütteks bituminoossetest savidest, argilliitidest ja liivakividest saadud süsinikurikas õli. Seejuures vōib rohkesti orgaanilist ainet sisaldavaid kivimeid kasutada otseselt põletamiseks ning orgaanilise aine poolest vaesemaid kivimeid kütteôli saamiseks. 


\section{H. STUMBUR}

\section{DIFFERENTS MOYENS D'UTILISATION DES ROCHES BITUMINEUSES SELON LEUR COMPOSITION LITHOLOGIQUE}

Dans le présent ouvrage l'auteur propose une classification des roches bitumineuses gui est fondée sur la qualité de leur matière organique de même que sur la composition substantielle de la partie inorganique des roches. D'après cette classification les roches sont réparties en trois groupes, à savoir:

Groupe «A»- qui comprend des calcaires bitumineux, des marnes et des koukersites (le gisement type de ce groupe, c'est le gisement dit Estonien);

Groupe $« B »-$ des argiles calcaires bitumineuses et des argiles en font partie (le gisement dit Kachpyrskoje représente le gisement type de ce groupe);

Groupe $« C »-$ où sont regroupés des argillites bitumineuses et des grès (le gisement de Türisalu, c'est le gisement type de ce groupe).

Les caractères essentiels du premier groupe des roches se traduisent par une forte teneur en hydrogène de la matière organique, un haut degré de transiormation de la matière organique en huile ainsi que par un pouvoir calorifique assez bas; le deuxième groupe se caractérise par une teneur moyenne en hydrogène et en carbone de la matière organique, par une assez faible teneur en huile et par un pouvoir calorifique bas par rapport à la quantité de la matière organique. Quant aux roches du troisième groupe, elles se distinguent par une haute teneur en carbone de la matière organique et par un pouvoir calorifique assez élevé. Les propriétés des roches bitumineuses ci-dessus indiquées ne dépendent ni de leur âge, ni de leur genèse.

Selon les propriétés différentes des roches bitumineuses, ces dernières peuvent être utilisées soit pour la production de matière première chimique, soit pour la production d'énergie calorifique. Comme matière première chimique il convient d'utiliser l'huile à haute teneur en hydrogène, extraite de calcaires bitumineux, de marnes et d'argiles calcaires; quant à la production d'énergie calorifique, c'est l'huile à haute teneur en carbone, extraite d'argiles bitumineuses, d'argillites et de grès que l'on peut utiliser. Il est à noter que des roches à haute teneur en matière organique peuvent être directement brûlées aux fours alors que des roches à faible teneur en matière organique sont susceptibles d'être traitées pour la production d'huile combustible.

$\mathrm{Vu}$ l'existence de divers moyens d'utilisation des roches bitumineuses à composition différente et le progrès dans le domaine d'équipement et de technologie minière, il s'avère nécessaire de tenir compte de réserves connues de toutes les roches carbonatées à une teneur en matière organique dépassant $7 \%$; il en est de même pour les roches argileuses ayant une teneur en matière organique qui dépasse $9 \%$ et pour les réserves d'aleurolites et de grès, dont la teneur en matière organique s'élève à plus de $8 \%$. 